\title{
Asupan protein dan fosfor, rasio fosfor - protein, dan kadar fosfor darah pada pasien gagal ginjal kronis dengan hemodialisis
}

Protein and phosphate intake, phosphate-protein ratio, and blood phosphate level in chronic kidney disease patients with hemodialysis

Ahmad Syauqy', Susetyowati ${ }^{2}$, Suhardi ${ }^{3}$

\begin{abstract}
Background: Hyperphosphatemia has become one of the main causes of death in CKD patients on HD. Thus, correction and prevention of hyperphospatemia is a major component in the management of HD patients. High protein diet in HD patients may lead to increased serum phosphate level due to mineral metabolism disorder associated with decreased glomerular filtration rate. In addition, high protein intake often followed by high phosphate intake as high protein foods also contains high phosphate and may cause hyperphosphatemia. Meanwhile, reduction of protein intake to control phosphate level was associated with decreased health and nutritional status in CKD patients. Therefore, appropriate phosphate-protein ratio is essential to provide adequate protein intake and avoid hyperphosphatemia.

Objective: To investigate the association between protein and phosphate intake, phosphate-protein ratio and blood phosphate level in CKD patients on routine HD.

Method: The study used an analytic observational method with cross sectional design. There were 100 subjects involved in this study. Subject characteristics, protein and phosphate intake, phosphate-protein ratio and intake of phosphate binders were obtained through interview and 3 x24 hour food record. Serum phosphate level was analyzed by inorganic phosphorus quantification method. Food processor was used to analyze the intake of protein and phosphate. Bivariate and multivariate tests with 95\% confidence interval were used to analyze the data.

Result: Adequate protein intake was observed among $38 \%$ subjects, while $46 \%$ of them have excess phosphate intake. High phosphate-protein ratio was found in $20 \%$ subjects. Most subjects did not take phosphate binders regularly (61\%) and have hyperphosphatemia (66\%). The average protein intake, phosphate intake, phosphate-protein ratio, and blood phosphate level were $1.1 \mathrm{~g} / \mathrm{kg} / \mathrm{d}, 13.5 \mathrm{mg} / \mathrm{kg} / \mathrm{d}, 12.8 \mathrm{mg} / \mathrm{g}$, and $5.6 \mathrm{mg} / \mathrm{dl}$, respectively. Bivariate test showed that there was a significant association between protein intake $(p=0.037 ; R P=2.78)$, phosphate intake $(p=0.005 ; R P=3.54)$, phosphate-protein ratio ( $p=0.045 ; R P=3.85)$, and blood phosphate level in CKD patients on routine HD. Multivariate analysis revealed that high phosphate intake and did not consume phosphate binders regularly were risk factors of hyperphosphatemia ( $p=0.000 ; O R=6.543$; $C l$ 95\%:2.357-18.164 dan $p=0.024 ; O R=3.413 ; C l 95 \%: 1.179 ; R^{2}=0.42$ ).

Conclusion: Consumtion of low phosphate foods and phosphate binders may reduce the risk of hyperphosphatemia in $C K D$ patients on routine $H D$.
\end{abstract}

KEY WORDS: hyperphosphatemia, protein intake, phosphor intake, phosphate-protein ratio, chronic renal failure, hemodialysis

\begin{abstract}
ABSTRAK
Latar belakang: Hiperfosfatemia adalah penyebab kematian pasien Gagal Ginjal Kronik (GGK) dengan hemodialisis (HD). Pencegahan hiperfosfatemia adalah komponen utama dari manajemen pasien HD. Diit tinggi protein pada pasien HD dapat mengakibatkan konsentrasi serum fosfor meningkat karena terjadinya gangguan metabolisme mineral yang berhubungan dengan penurunan fungsi laju filtrasi glomerulo ginjal. Asupan tinggi protein seringkali diikuti dengan asupan fosfor yang tinggi karena bahan makanan tinggi protein banyak mengandung fosfor. Sebaliknya, pengurangan asupan protein untuk mengontrol fosfor akan berhubungan dengan daya tahan tubuh. Diperlukan rasio fosfor - protein yang baik untuk mencukupi asupan protein dan menghindari hiperfosfatemia.

Tujuan: Mengetahui hubungan asupan protein, fosfor, dan rasio fosfor-protein dengan kadar fosfor darah pada pasien penderita GGK dengan HD.

Metode: Penelitian observasional analitik dengan pendekatan cross-sectional yang dilakukan pada 100 subjek penelitian. Karakteristik subjek, asupan protein dan fosfor, rasio fosfor-protein, penggunaan obat pengikat fosfot diperoleh lewat wawancara dan 3x24 jam food records. Kadar fosfor darah dianalisis dengan metode fosfor anorganik. Data kemudian dianalisis dengan uji bivariat dan multivariat dengan tingkat kepercayaan 95\%.
\end{abstract}

\footnotetext{
${ }^{1}$ Korespondensi: Program Studi IImu Gizi, Fakultas Kedokteran Universitas Diponegoro, Jl. dr. Sutomo No. 14, Semarang Jawa Tengah, e-mail: bang_yoki@yahoo.com

2 Program Studi Gizi Kesehatan, Fakultas Kedokteran Universitas Gadjah Mada, Jl. Farmako, Sekip Utara, Yogyakarta 55281, e-mail: susetyowati2000@yahoo.com

${ }^{3}$ Instalasi Hemodialisis Rumah Sakit Umum Pusat Dr. Sardjito, Jl. Kesehatan No 1, Sekip, Yogyakarta
} 


\begin{abstract}
Hasil: Asupan protein adekuat ditemukan pada 38\% subjek, sementara $46 \%$ mempunyai asupan fosfor berlebih. Rasio fosforprotein tinggi ditemukan pada $20 \%$ subjek. Sebagian besar subjek mengonsumsi obat pengikat fosfor secara tidak teratur (61\%) dan mengalami hiperfosfatemia (66\%). Rerata asupan protein, fosfor, dan rasio fosfor-protein dari makanan adalah $1,1 \mathrm{~g} / \mathrm{kgBB} / \mathrm{hari}, 13,5 \mathrm{mg} / \mathrm{kgBB} / \mathrm{hari}$, dan $12,8 \mathrm{mg} / \mathrm{g}$ dengan rerata kadar fosfor darah 5,6 mg/dl. Uji bivariat menunjukkan terdapat hubungan antara asupan protein $(p=0,032 ; R P=2,78)$, fosfor $(p=0,005 ; R P=3,54)$, rasio fosfor-protein $(p=0,045$; $R P=3,85)$, dan obat pengikat fosfor ( $p=0,001 ; R P=1,71)$ dengan kadar fosfor darah. Analisis lebih lanjut dengan uji multivariat menunjukkan bahwa tidak menggunakan obat pengikat fosfor dan asupan fosfor yang tinggi merupakan faktor risiko terjadinya hiperfosfatemia ( $p=0,000 ; O R=6,543 ; \mathrm{Cl} 95 \%: 2,357-18,164$ dan $p=0,024 ; O R=3,413 ; \mathrm{Cl} 95 \%: 1,179 ; R^{2}=0,42$ )

Simpulan: Konsumsi bahan makanan dengan kadar fosfor rendah dan obat pengikat fosfor secara teratur dapat menurunkan risiko terjadinya hiperfosfatemia pada pasien GGK dengan HD rutin.
\end{abstract}

KATA KUNCI: hiperfosfatemia, asupan protein, asupan fosfor, rasio fosfor - protein, gagal ginjal kronis, hemodialisis

\section{PENDAHULUAN}

Prevalensi gagal ginjal kronis (GGK) meningkat tiap tahunnya dan apabila tidak ditangani dengan baik akan menyebabkan kematian (1-3). Hemodialisis (HD) adalah salah satu dari pilihan terapi pasien GGK terminal. Salah satu penyebab kematian pada GGK dengan HD adalah penyakit kardiovaskuler yang berhubungan dengan tingginya kadar fosfor darah (hiperfosfatemia) akibat penurunan fungsi ginjal $(2,4,5)$.

Koreksi dan pencegahan hiperfosfatemia merupakan komponen utama dari manajemen GGK dengan HD. Protein merupakan komponen penting pada terapi pasien dengan GGK. The National Kidney Foundation Kidney Disease Outcomes Quality Initiative (NKF K/DOQI) merekomendasikan bagi pasien dialisis untuk diberikan asupan tinggi protein. Namun, makanan yang kandungan proteinnya tinggi adalah sumber utama dari fosfor yang akan berdampak pada hiperfosfatemia (1).

Penelitian yang dilakukan di Amerika Serikat menemukan adanya hubungan antara asupan protein dengan kadar fosfor darah. Diit tinggi protein pada pasien HD dapat mengakibatkan hiperfosfatemia karena adanya gangguan metabolisme mineral yang berhubungan dengan penurunan fungsi laju filtrasi glomerulus (LFG) ginjal. Hal ini sering dijumpai selama perawatan medis pasien HD (6). Penelitian di Italia juga menemukan perbedaan asupan protein pada pasien dengan hiperfosfatemia yang cenderung lebih tinggi dibandingkan dengan pasien yang normal (7).

Selain protein, peningkatan asupan fosfor juga dapat menyebabkan hiperfosfatemia (4). Makanan dengan kandungan protein tinggi merupakan sumber utama dari fosfor. Protein merupakan komponen penting pada terapi pasien dengan GGK, maka dianjurkan pasien memilih makanan dengan rasio fosfor - protein yang rendah untuk menjaga kadar fosfor darahnya tetap stabil. Selain dari asupan makanan, pemberian obat pengikat fosfat tetap diperlukan untuk mengontrol fosfor darah (8). Tujuan penelitian ini adalah untuk mengetahui hubungan asupan protein, fosfor, dan rasio fosfor - protein dengan kadar fosfor darah pada pasien penderita penyakit GGK dengan HD.

\section{BAHAN DAN METODE}

Penelitian ini merupakan penelitian observasional analitik dengan rancangan cross-sectional yang dilaksanakan pada bulan Oktober sampai Desember 2010 di Yayasan Ginjal Diatrans Indonesia, Jakarta. Populasi penelitian adalah semua pasien yang menjalani rawat jalan hemodialisis di Yayasan Ginjal Diatrans Indonesia. Subjek penelitian adalah pasien penderita penyakit gagal ginjal kronis serta menjalani HD rutin di Yayasan Ginjal Diatrans Indonesia yang diambil secara purposive dan diperoleh sebanyak 100 orang. Kriteria inklusi yaitu bersedia ikut serta dalam penelitian dengan menandatangani informed consent, menjalani HD rutin 2 kali per minggu, dan sudah menjalani HD minimal 2 bulan sedangkan kriteria eksklusi adalah subjek yang menjalani rawat inap di rumah sakit selama 3 bulan terakhir sebelum penelitian ini dimulai.

Besar sampel dengan tingkat kepercayaan (a) 95\% ditentukan menggunakan rumus pengujian hipotesis untuk proporsi tunggal dengan kekuatan uji yang diinginkan $(\beta)$ adalah $84 \%$, proporsi $1(\mathrm{P} 1)=0,75$ dan proporsi $2(\mathrm{P} 2)=0,40$ sehingga jumlah sampel minimal sebesar 88 subjek. Sampel yang mengikuti sampai akhir penelitian sebanyak 100 orang. Variabel independen adalah asupan protein, asupan fosfor, dan rasio fosfor - protein, variabel dependen adalah kadar fosfor darah, dan variabel pengganggu adalah penggunaan obat pengikat fosfat. Alat penelitian yang digunakan berupa food record untuk menilai asupan protein, fosfor, dan ratio fosfor - protein kemudian diolah menggunakan food processor. Selain itu juga digunakan food model untuk peraga makanan, timbangan digital untuk mengukur berat badan (BB), dan microtoise untuk mengukur tinggi badan (TB) sedangkan untuk serum fosfor dilakukan tes uji darah fosfor anorganik di laboratorium Kimia Farma.

Asupan protein dan fosfor adalah rata-rata jumlah protein dan fosfor dari makanan dan minuman dalam satuan gram ( $\mathrm{g}$ ) yang diperoleh dengan menggunakan food record selama 3 hari. Asupan protein dikategorikan menjadi tidak adekuat $(<1,2 \mathrm{~g} / \mathrm{kg} \mathrm{BB} /$ hari) dan adekuat $(\geq 1,2 \mathrm{~g} / \mathrm{kg} \mathrm{BB} /$ hari) sedangkan asupan fosfor dikategorikan menjadi cukup ( $\leq 17 \mathrm{mg} / \mathrm{kg} \mathrm{BB}$ ) dan lebih $(>17 \mathrm{mg} / \mathrm{kg}$ BB) (9). Rasio fosfor - protein adalah perbandingan 
kandungan fosfor dengan protein yang terdapat pada makanan sumber protein yang dikonsumsi dalam satuan miligram/gram $(\mathrm{mg} / \mathrm{g})$ dan dikategorikan menjadi rendah bila perbandingan asupan fosfor dengan protein kurang dari atau sama dengan $15 \mathrm{mg} / \mathrm{g} / \mathrm{hari}$ dan tinggi bila perbandingan asupan fosfor dengan protein lebih dari 15 $\mathrm{mg} / \mathrm{g} / \mathrm{hari}$ (8). Serum fosfor adalah kadar fosfor darah (mg/ dl) yang diukur pada saat sebelum HD dan dikategorikan menjadi kadar fosfor darah tinggi (hiperfosfatemia) bila lebih dari $5 \mathrm{mg} / \mathrm{dl}$ dan normal bila kurang dari atau sama dengan $5 \mathrm{mg} / \mathrm{dl}$ (9). Penggunaan obat pengikat fosfat yang rutin dikonsumsi subjek, diperoleh dengan menggunakan food record selama 3 hari dengan kategori teratur bila diminum rutin atau berbarengan waktu makan dan tidak teratur bila tidak diminum rutin atau tidak berbarengan waktu makan (9).

Pengambilan serum fosfor dilakukan oleh tim keperawatan dan analis kesehatan berdasarkan prosedur tetap dan diuji di laboratorium. Pengambilan data asupan makan dilakukan oleh ahli gizi sedangkan serum darah di bawah tanggungjawab dokter di Yayasan Ginjal Diatrans Indonesia. Uji satistik menggunakan uji Chi-Square dan regresi linear berganda dengan interval kepercayaan (IK) 95\%. Penelitian ini telah memperoleh kelaikan etik dari Komisi Etik Penelitian dan Kesehatan Fakultas Kedokteran Universitas Gadjah Mada nomor KE/FK/669/EC.

\section{HASIL}

\section{Karakteristik subjek penelitian}

Tabel 1 menunjukkan bahwa lebih banyak subjek yang berjenis kelamin laki-laki (67\%) dengan usia produktif (27\%). Temuan penting adalah banyaknya jumlah penderita HD (85\%) dalam usia muda (<60 tahun) dan sebagian besar telah menjalani HD lebih dari 2 tahun.

Asupan protein, asupan fosfor, rasio fosfor - protein, penggunaan obat pengikat fosfat, dan kadar fosfor darah

Tabel 2 menunjukkan sebagian besar subjek menderita hiperfosfatemia (66\%) dengan asupan protein subjek sebagian besar tergolong tidak adekuat (62\%), asupan fosfor sebagian besar tergolong cukup (54\%), dan rasio fosfor - protein sebagian besar tergolong rendah (80\%). Namun, Tabel 3 menunjukkan rerata asupan protein dan fosfor di atas angka kecukupan gizi (AKG) yang dianjurkan yaitu berturut-turut $55 \mathrm{~g}$ dan $500 \mathrm{mg}$.

Hubungan asupan protein, asupan fosfor, rasio fosfor - protein, dan penggunaan obat pengikat fosfat dengan kadar fosfor darah

Tabel 4 menunjukkan 4 variabel yang dianalisis secara bivariat menunjukkan hubungan bermakna
Tabel 1. Distribusi frekuensi karakteristik subjek penelitian

\begin{tabular}{|c|c|c|}
\hline Karakteristik & $\mathbf{n}$ & $\%$ \\
\hline \multicolumn{3}{|l|}{ Jenis kelamin } \\
\hline Laki-laki & 67 & 67 \\
\hline Perempuan & 33 & 33 \\
\hline \multicolumn{3}{|l|}{ Umur (tahun) } \\
\hline $20-30$ & 13 & 13 \\
\hline $31-40$ & 22 & 22 \\
\hline $41-50$ & 23 & 23 \\
\hline $51-60$ & 27 & 27 \\
\hline $61-70$ & 9 & 9 \\
\hline$>70$ & 6 & 6 \\
\hline \multicolumn{3}{|l|}{ Tingkat pendidikan } \\
\hline SD & 6 & 6 \\
\hline SMP & 23 & 23 \\
\hline SMA & 53 & 53 \\
\hline PT & 18 & 18 \\
\hline \multicolumn{3}{|l|}{ Status pernikahan } \\
\hline Menikah & 80 & 80 \\
\hline Sendiri & 20 & 20 \\
\hline \multicolumn{3}{|l|}{ Asuransi kesehatan } \\
\hline SKTM & 55 & 55 \\
\hline Gakin & 10 & 10 \\
\hline Jamkesmas & 29 & 29 \\
\hline Pribadi & 6 & 6 \\
\hline \multicolumn{3}{|l|}{ Lama menjalani HD (bulan) } \\
\hline $4-24$ & 44 & 44 \\
\hline $25-48$ & 40 & 40 \\
\hline $49-72$ & 14 & 14 \\
\hline$>72$ & 2 & 2 \\
\hline \multicolumn{3}{|l|}{ Kategori status gizi } \\
\hline Kurang & 25 & 25 \\
\hline Normal & 53 & 53 \\
\hline Lebih & 22 & 22 \\
\hline \multicolumn{3}{|l|}{ Gangguan gastrointestinal } \\
\hline Ya & 63 & 63 \\
\hline Tidak & 37 & 37 \\
\hline
\end{tabular}

Tabel 2. Distribusi penggunaan pengikat fosfat, asupan protein, asupan fosfor, rasio fosfor - protein, dan kadar fosfor darah

\begin{tabular}{lcc}
\hline \multicolumn{1}{c}{ Variabel } & $\mathbf{n}$ & $\%$ \\
\hline Penggunaan obat pengikat fosfat & & \\
$\quad$ Teratur & 39 & 39 \\
$\quad$ Tidak teratur & 61 & 61 \\
Asupan protein & & \\
$\quad$ Tidak adekuat $(<1,2 \mathrm{~g} / \mathrm{Kg} \mathrm{BB} / \mathrm{hari})$ & 62 & 62 \\
$\quad$ Adekuat $(\geq 1,2 \mathrm{~g} / \mathrm{Kg} \mathrm{BB} / \mathrm{hari})$ & 38 & 38 \\
Asupan fosfor & & \\
$\quad$ Cukup $(\leq 17 \mathrm{mg} / \mathrm{kg} \mathrm{BB})$ & 54 & 54 \\
$\quad$ Lebih $(>17 \mathrm{mg} / \mathrm{kg} \mathrm{BB})$ & 46 & 46 \\
Rasio fosfor-protein & & \\
$\quad$ Rendah $(\leq 15 \mathrm{mg} / \mathrm{g})$ & 80 & 80 \\
$\quad$ Tinggi $(>15 \mathrm{mg} / \mathrm{g})$ & 20 & 20 \\
Kadar fosfor darah & & \\
$\quad$ Normal $(\leq 5 \mathrm{mg} / \mathrm{dl})$ & 34 & 34 \\
$\quad$ Hiperfosfatemia $(>5 \mathrm{mg} / \mathrm{dl})$ & 66 & 66 \\
\hline
\end{tabular}


Tabel 3. Deskripsi asupan protein, fosfor, rasio fosfor protein, dan kadar fosfor darah

\begin{tabular}{lcccc}
\hline \multicolumn{1}{c}{ Parameter } & $\mathbf{n}$ & $\mathbf{X}$ & Sd & Min-maks \\
\hline Asupan protein $(\mathrm{g} / \mathrm{kgBB})$ & 100 & 1,1 & $\pm 0,38$ & $0,5-1,8$ \\
Asupan fosfor $(\mathrm{mg} / \mathrm{kgBB})$ & 100 & 13,5 & $\pm 4,3$ & $6,2-20,8$ \\
Rasio fosfor - protein $(\mathrm{mg} / \mathrm{g})$ & 100 & 12,8 & $\pm 2,1$ & $9-17,9$ \\
Kadar fosfor darah $(\mathrm{mg} / \mathrm{dl})$ & 100 & 5,6 & $\pm 2,19$ & $2-11,1$ \\
\hline
\end{tabular}

Tabel 4. Hubungan asupan protein, asupan fosfor, rasio fosfor - protein, dan penggunaan obat pengikat fosfat dengan kadar fosfor darah

\begin{tabular}{|c|c|c|c|c|c|c|c|c|}
\hline \multirow{3}{*}{ Variabel } & \multicolumn{4}{|c|}{ Kategori kadar fosfor darah } & \multirow{2}{*}{\multicolumn{2}{|c|}{ Jumlah }} & \multirow{3}{*}{$\mathbf{p}$} & \multirow{3}{*}{$\begin{array}{c}\mathrm{RP} \\
(95 \% \mathrm{Cl})\end{array}$} \\
\hline & \multicolumn{2}{|c|}{ Hiperfosfatemia } & \multicolumn{2}{|c|}{ Normal } & & & & \\
\hline & $\mathbf{n}$ & $\%$ & $\mathbf{n}$ & $\%$ & $\mathbf{n}$ & $\%$ & & \\
\hline \multicolumn{9}{|l|}{ Asupan protein } \\
\hline Tidak adekuat & 30 & 78,9 & 8 & 21,1 & 38 & 100 & \multirow[t]{2}{*}{0,032} & 1,36 \\
\hline Adekuat & 36 & 58,1 & 26 & 41,9 & 62 & 100 & & $(1,04-1,77)$ \\
\hline \multicolumn{9}{|l|}{ Asupan fosfor } \\
\hline Cukup & 37 & 80,4 & 9 & 19,6 & 46 & 100 & \multirow[t]{2}{*}{0,005} & 1,49 \\
\hline Lebih & 29 & 53,7 & 25 & 46,3 & 54 & 100 & & $(1,12-1,99)$ \\
\hline \multicolumn{9}{|l|}{ Rasio fosfor-protein } \\
\hline Rendah & 49 & 61,2 & 31 & 38,8 & 80 & 100 & \multirow[t]{2}{*}{0,045} & 1,39 \\
\hline Tinggi & 17 & 85 & 3 & 15 & 20 & 100 & & $(1,08-1,79)$ \\
\hline \multicolumn{9}{|c|}{ Penggunaan obat pengikat fosfat } \\
\hline Teratur & 48 & 78,7 & 13 & 21,3 & 61 & 100 & \multirow[t]{2}{*}{0,001} & 1,71 \\
\hline Tidak teratur & 18 & 46,2 & 21 & 53,8 & 39 & 100 & & $(1,19-2,45)$ \\
\hline
\end{tabular}

Tabel 5. Analisis multivariat faktor risiko hiperfosfatemia

\begin{tabular}{|c|c|c|c|c|c|}
\hline Variabel & $\mathbf{p}$ & SE & OR & \multicolumn{2}{|c|}{$\mathrm{Cl} 95 \%$} \\
\hline Penggunaan obat pengikat fosfat & 0,000 & 0,528 & 6,543 & 2,357 & 18,164 \\
\hline Asupan protein & 0,079 & 0,587 & 2,730 & 0,890 & 9,879 \\
\hline Asupan fosfor & 0,024 & 0,556 & 3,413 & 1,179 & 9,879 \\
\hline Rasio fosfor - protein & 0,168 & 0,778 & 2,922 & 0,636 & 13,415 \\
\hline
\end{tabular}

terhadap kadar fosfor darah. Selanjutnya dilakukan analisis multivariat terhadap 4 variabel yang berhubungan dengan hiperfosfatemia (Tabel 5). Faktor risiko untuk hiperfosfatemia adalah penggunaan obat pengikat fosfat tidak teratur $(p=0,000$; OR=6,543; Cl 95\%:2,357$18,164)$ dan asupan fosfor tinggi $(p=0,024$; OR=3,413; $\mathrm{Cl} 95 \%: 1,179-9,879)$. Subjek yang tidak mengonsumsi obat pengikat fosfat secara teratur berisiko 6,5 kali untuk menderita hiperfosfatemia dibandingkan dengan subjek yang teratur sedangkan subjek dengan asupan fosfor tinggi mempunyai risiko 3,5 kali untuk terkena hiperfosfatemia dibandingkan subjek dengan asupan fosfor rendah.

\section{BAHASAN}

Kadar fosfor darah pada subjek penelitian ini sebagian besar tergolong tinggi. Penelitian yang dilakukan di Denpasar menemukan 100\% pasien dengan hiperfosfatemia (10). Penelitian di Italia menunjukkan rerata kadar fosfat darah subjek penelitian adalah 5,74 $\pm 1,57$ $\mathrm{mg} / \mathrm{dl}$ dan lebih dari $50 \%$ dengan hiperfosfatemia $(5,11)$. Kondisi hiperfosfatemia harus segera ditangani karena merupakan faktor pencetus penyakit kardiovaskuler (12). Hasil penelitian di Amerika Serikat menunjukkan adanya hubungan antara kadar serum fosfor tinggi dengan meningkatnya angka kematian pasien GGK dan menyimpulkan bahwa ada gangguan metabolisme mineral yang memberikan pengaruh kardiovaskuler pada penderita GGK (6).

Secara keseluruhan asupan makan subjek tergolong kurang, hal ini berakibat rendahnya asupan protein dan fosfor. Rendahnya asupan makan dapat terjadi karena subjek mengalami penurunan nafsu makan. Asupan makan sebagian pasien HD sulit untuk dipenuhi karena seringkali mengalami perubahan indra pengecap atau kehilangan cita rasa ataupun adanya gangguan gastrointestinal (9). K/DOQI merekomendasikan total asupan protein pada pasien GGK dengan HD rutin adalah lebih dari atau sama dengan $1,2 \mathrm{~g} / \mathrm{kg}$ BB untuk menjaga keseimbangan nitrogen dan kehilangan protein saat dialisis sedangkan untuk asupan fosfor maksimal 1000 $\mathrm{mg} /$ hari (9).

Hasil analisis menunjukkan adanya hubungan antara asupan protein adekuat dan asupan fosfor berlebih dengan 
hiperfosfatemia. Penelitian ini sejalan dengan penelitian di Amerika Serikat yang menemukan adanya hubungan antara asupan protein dan fosfor yang tinggi dengan hiperfosfatemia $(4,6)$. Hal berbeda dengan penelitian di Italia yang menyatakan bahwa tidak ada hubungan antara asupan protein dengan kadar fosfor darah. Namun, penelitian tersebut menemukan asupan protein pasien penderita hiperfosfatemia cenderung lebih tinggi dibandingkan pasien yang normal meskipun secara statistik tidak berhubungan bermakna (7). Membatasi asupan fosfor dan meningkatkan asupan protein dianjurkan pada pasien GGK lanjut, terutama yang menjalani HD. Konsumsi protein yang tinggi diharapkan akan menurunkan angka kematian karena dapat meningkatkan status gizi pasien, tetapi diperlukan obat pengikat fosfat untuk bisa mengontrol kadar fosfor darah (6).

Penelitian di Amerika Serikat melaporkan bahwa pemberian obat pengikat fosfat perlu diberikan pada pasien GGK. Namun, sebagian besar pemberiannya tidak efektif karena rendahnya tingkat kepatuhan pasien yang disebabkan terlalu banyak beban obat yang harus diminum setiap harinya (12). Obat pengikat fosfat yang ideal adalah yang memiliki rasa enak (dapat diterima), efektif (memiliki afinitas tinggi), tanpa efek samping, bekerja dalam waktu lama, dan murah. Pengikat fosfat yang tersedia saat ini, belum ada yang memenuhi kriteria tersebut. Pengikat fosfat biasanya dibagi menjadi pengikat fosfat yang mengandung kalsium dan tidak mengandung kalsium. Pemberian obat pengikat fosfat harus dibarengi pada saat makan dan tidak boleh diberikan bersamaan dengan pemberian besi karena akan membentuk senyawa yang sukar larut di dalam usus (13).

Pasien yang tidak teratur mengonsumsi obat pengikat fosfat disebabkan oleh kurangnya tingkat kepatuhan pasien, selain itu juga karena penggunaan yang tidak sesuai dengan petunjuk yang diberikan dokter atau tenaga medis lain mengenai waktu dan cara konsumsi obat tersebut. Hal ini akan berdampak pada profil fosfor darah. Dengan demikian, konsumsi obat pengikat fosfat secara teratur merupakan salah satu manajemen perawatan pasien dialisis yang penting untuk dilakukan (12).

Rasio fosfor - protein diperoleh berdasarkan asupan protein pasien dengan menghitung perbandingan kandungan fosfor dengan protein yang dikonsumsi subjek penelitian. Protein hewani memiliki rasio perbandingan yang lebih rendah ( $\pm 11 \mathrm{mg}$ fosfor per $1 \mathrm{~g}$ protein) dibandingkan protein nabati $( \pm 20 \mathrm{mg}$ fosfor per $1 \mathrm{~g}$ protein). Penelitian di Amerika Serikat pada pasien HD dengan asupan protein yang cenderung meningkat, akan menurunkan serum fosfor dari waktu ke waktu sehingga peluang hidup akan lebih lama. Oleh karena itu, diperlukan asupan makanan dengan rasio perbandingan antara fosfor - protein yang rendah seperti putih telur dan beberapa jenis ikan sedangkan yang memiliki rasio tinggi perlu dihindari seperti susu, kreamer, keju, susu kedelai, biskuit, hati ayam, biji-bijian, dan kacang-kacangan (8).

Tingginya asupan fosfor dan rasio asupan fosfor dibandingkan protein dalam suatu bahan makanan dapat meningkatkan risiko kematian pada pasien GGK dengan HD rutin yang diduga disebabkan oleh hiperfosfatemia. Faktor yang mempengaruhi asupan makan pada penderita GGK dengan HD adalah gangguan ganstrointestinal, anoreksi, mual, dan muntah. Konsumsi sumber protein dengan perbandingan fosfor dan protein rendah akan mengontrol serum fosfor darah dan dapat menurunkan angka kematian pada pasien dengan HD. Rasio fosfor - protein rendah pada makanan dapat meningkatkan status gizi dan menurunkan risiko malnutrisi protein pada pasien HD selain menjaga kadar fosfor darah tetap normal $(4,8)$.

Hasil penelitian ini menunjukkan adanya beberapa pasien yang mengonsumsi makanan olahan atau awetan yang memiliki rasio fosfor lebih tinggi karena didalamnya terkandung zat penambah fosfor. Makanan tersebut adalah susu dan produk olahannya seperti keju. Tidak sedikit pasien yang takut mengalami penurunan kadar hemoglobin $(\mathrm{Hb})$ sehingga mereka mengonsumsi makanan yang dapat meningkatkan $\mathrm{Hb}$ padahal makanan tersebut memiliki kandungan fosfor tinggi seperti hati sapi. Sebagian pasien juga ada yang mengonsumsi bahan makanan sumber protein dari jenis kacang-kacangan seperti kacang merah dan kacang hijau. Sebuah penelitian di Amerika Serikat menemukan perbedaan jumlah asupan fosfor pada subjek yang diberikan makanan tinggi protein dengan fosfor aditif dibandingkan makanan tinggi protein dengan rasio fosfor - protein rendah. Ternyata subjek yang diberikan makanan tinggi protein dengan fosfor aditif mempunyai rasio fosfor - protein yang lebih tinggi dibandingkan subjek yang diberikan makanan tinggi protein dengan rasio fosfor - protein rendah (4).

Nilai $R^{2}$ dari hasil uji multivariat sebesar 0,42 yang berarti asupan protein, fosfor, rasio fosfor-protein, dan penggunaan obat pengikat fosfat hanya memberikan kontribusi sebesar $42 \%$ terhadap kejadian hiperfosfatemia sedangkan sisanya dipengaruhi oleh faktor lain seperti besarnya kerusakan ginjal, lamanya menjalani HD, dan faktor lainnya. Penggunaan obat pengikat fosfat memiliki hubungan paling kuat dibandingkan variabel lainnya. Namun, masih banyak subjek yang tidak mengonsumsi obat tersebut secara teratur. Pasien HD yang menerima terapi obat pengikat fosfat tidak mencapai serum fosfor normal karena hanya sebagian kecil dari pasien yang patuh mengonsumsi obat pengikat fosfat. Sebagian besar pasien dalam penelitian ini menggunakan obat pengikat fosfat dalam bentuk kalsium karbonat. Banyaknya jenis obat yang diberikan kepada pasien akan mempengaruhi kepatuhan dan keteraturan dalam mengonsumsi obatobatan tersebut $(5,9)$. 


\section{SIMPULAN DAN SARAN}

Asupan protein, asupan fosfor, rasio fosfor-protein, dan obat pengikat fosfat menunjukkan hubungan yang bermakna dengan kadar fosfor darah pada pasien GGK dengan HD rutin. Variabel yang bermakna secara mandiri maupun bersamaan mempengaruhi kadar fosfor darah adalah penggunaan obat pengikat fosfat dan asupan fosfor.

Asupan protein yang cukup bagi penderita GGK dengan HD tetap diperlukan untuk mencegah malnutrisi, tetapi perlu adanya pemilihan bahan makanan sumber protein yang mempunyai rasio fosfor-protein rendah. Bahan makanan sumber fosfor selain dari protein perlu dibatasi untuk menjaga kadar fosfor darah tetap normal. Dianjurkan mengonsumsi obat pengikat fosfat dengan tepat dan teratur. Setiap pasien HD dianjurkan untuk mendapat panduan dari ahli gizi dalam merencanakan diit dengan menggunakan bahan makanan sumber protein berdasarkan rasio fosfor - protein yang dianjurkan.

\section{RUJUKAN}

1. Renal Data System. USRDS 2003 annual data report: atlas of end-stage renal disease in the United States. Bethesda, MD: National Institutes of Health, National Institute of Diabetes and Digestive and Kidney Diseases; 2003.

2. Schiffrin EL, Lipman ML, Mann JF. Chronic kidney disease: effects on the cardiovascular system. Circulation 2007;116(1):85-97.

3. Cases Amenos A, Gonzalez-Juanatey JR, Conthe Gutierrez P, Matali Gilarranz A, Garrido Costa C. Prevalence of chronic kidney disease in patients with or at a high risk of cardiovascular disease. Rev Esp Cardiol 2010;63(2):225-8.

4. Noori N, Kalantar-Zadeh K, Kovesdy CP, Bross R, Benner D, Kopple JD. Association of dietary phosphorus intake and phosphorus to protein ratio with mortality in hemodialysis patients. Clin J Am Soc Nephrol 2010;5(4):683-92.
5. Achinger SG, Ayus JC. Left ventricular hypertrophy: is hyperphosphatemia among dialysis patients a risk factor?. J Am Soc Nephrol 2006;17(12 Suppl 3):S25561.

6. Shinaberger CS, Greenland S, Kopple JD, Wyck DV, Mehrotra R, Kovesdy CP, Kalantar-Zadeh K. Is controlling phosphorus by decreasing dietary protein intake beneficial or harmful in persons with chronic kidney disease. Am J Clin Nutr 2008;88(6):1511-8.

7. Cupisti A, D'Alessandro C, Baldi R, Barsotti G. Dietary habits and counseling focused on phosphate intake in hemodialysis patients with hyperphosphatemia. J Ren Nutr 2004;14(4):220-5.

8. Kalantar-Zadeh K, Gutekunst L, Mehrotra R, Kovesdy CP, Bross R, Shinaberger CS, Noori N, Hirschberg R, Benner D, Nissenson AR, Kopple JD. Understanding sources of dietary phosphorus in the treatment of patients with chronic kidney disease. Clin J Am Soc Nephrol 2010;5(3):519-30.

9. National Kidney Foundation. K/DOQI clinical practice guidelines for bone metabolism and disease in chronic kidney disease. Am J Kidney Dis 2003;42(4 Suppl 3):S1-201.

10. Suwitra K. Pola kadar fosfat, kalsium dan hormon paratiroid pada penyakit ginjal terminal dengan HD regular di RSUP Sanglah Denpasar. Acta Medica Indonesiana 2000;XXXII(4):167-70.

11. Gallieini M, Cucciniello E, D’Amaro E, Fatuzzo P, Gaggiotti A, Maringhini S, Rotolo U, Brancaccio D; CARDIALISI Study Group. Calcium, phosphate and PTH levels in hemodialysis population: a multicenter study. J Nephrol 2002;15(2):165-70.

12. Chiu YW, Teitelbaum I, Misra M, de Leon EM, Adzize T, Mehrotra R. Pill burden, adherence, hyperphosphatemia, and quality of life in maintenance dialysis patients. Clin J Am Soc Nephrol 2009;4(6):1089-96.

13. Rees L, Shroff RC. Phosphate binders in CKD: chalking out the differences. Pediatr Nephrol 2010;25(3):38594. 